\title{
Molecular Phylogeny and Biogeography of the Native Rodents of Madagascar (Muridae: Nesomyinae): A Test of the Single-Origin Hypothesis
}

\author{
Sharon A. Jansa, ${ }^{*, 1}$ Steven M. Goodman, $\dagger$ and Priscilla K. Tucker* \\ *Museum of Zoology and Department of Biology, U niversity of Michigan, Ann Arbor, Michigan 48109; and \\ †The Field Museum of N atural History, Roosevelt Road at Lake Shore Drive, Chicago, Illinois 60615; and \\ WWF, B.P. 738, Antananarivo (101), Madagascar
}

Accepted for publication October 12, 1998

Complete nucleotide sequences from the mitochondrial cytochrome b gene (1143 bp) were used to investigate the phylogenetic relationships among the native rodents of Madagascar. Specifically, this study examines whether the nine genera of nesomyines form a monophyletic group relative to other Old World murids. All nine of the nesomyine genera, including multiple individuals from 15 of the 21 described species, were included in the analysis, and their monophyly was assessed relative to the murid subfamilies Mystromyinae, Petromyscinae, Dendromurinae, C ricetomyinae, Murinae, Rhizomyinae, and $\mathrm{C}$ alomyscinae. Phylogenetic analysis of the resulting 95 taxa and 540 characters resulted in 502 equally parsimonious cladograms. The strict consensus tree weakly refutes the monophyly of Nesomyinae and suggests that the Malagasy rodents form a clade with dendromurines (as represented by Steatomys) and the African rhizomyine Tachyoryctes. The cladogram strongly refutes the association of the South African genus Mystromys with the Malagasy genera and suggests that Petromyscus and Mystromys

\footnotetext{
${ }^{1}$ Present address: Department of Mammalogy, American Museum of Natural History, Central Park West at 79th Street, New York, NY 10024.
}

form a monophyletic group. We provide the first explicitly phylogenetic scenario for the biogeographic history of nesomyine rodents. 0 ur phylogenetic hypothesis indicates: (1) rodents invaded Madagascar only once, (2) they came from Asia not from Africa as is commonly assumed, and (3) there was a secondary invasion of rodents from Madagascar into Africa. (1) 1999 The Willi Hennig Society

\section{INTRODUCTION}

The native rodents of Madagascar are a diverse taxonomic assemblage of uncertain phylogenetic affinities. This small assemblage of nine genera includes such diverse forms as the vole-like marsh rat Brachyuromys, the scansorial tufted-tail rat Eliurus, the semifossorial giant rat Hypogeomys, and the saltatorial, gerbil-like Macrotarsomys. All 21 species of Malagasy rodents are currently assigned to the subfamily Nesomyinae, part of the large, cosmopolitan family Muridae (Carleton and Musser, 1984; Musser and Carleton, 1993). This classification implies that Madagascar's rodents form a monophyletic group. However, the current classification of nesomyine rodents is based more on their 
shared distribution on Madagascar than on any shared organismal characters, and it has been cautioned that "each of the genera could stand as a separate tribe or subfamily were it not for the centripetal taxonomic influence provided by their common distribution on Madagascar" (Carleton and Musser, 1984:343).

There is little doubt that the nesomyine rodents are part of Muridae, the speciose assemblage of rats, mice, and voles diagnosed by a myomorphous, sciurognathic jaw structure. However, the placement of the nine Malagasy genera relative to other members of Muridae is controversial. Ellerman $(1940,1941)$ could not find reason to include all nesomyine genera in one subfamily. Under his classification, Eliurus became part of Murinae, Brachytarsomys was allied with the Holarctic Arvicolinae, Brachyuromys and Tachyoryctes formed a separate subfamily (Tachyoryctinae), while the remaining genera were either given their own subfamily (Gymnuromyinae) or collected under Cricetinae (Table 1). This classification has not been widely adopted, but it is the most radical formalization of the concept that Madagascar's rodents do not form a natural group. In contrast, Simpson (1945) maintained that nesomyine rodents are monophyletic and included them as a single subfamily of his Cricetidae. Other proponents of nesomyine monophyly (Lavocat, 1978; Chaline et al., 1977) group the Malagasy rodents as part of a overarching family Nesomyidae which includes the Malagasy rodents and a number of fossil and "archaic" African muroids (Table 1).

The controversy surrounding the systematics of nesomyine rodents is inseparable from the interpretation of their origin. The focal questions are whether rodents arrived on Madagascar once and radiated in situ or several different times, in which case Nesomyinae, as currently defined, would be polyphyletic. Attempts to infer the origin of nesomyine rodents using fossil data have failed due to the absence of a Tertiary fossil record on Madagascar, and the proposed link between the lower Miocene Kenyan rodent Protarsomys macinnesi and nesomyines, particularly Macrotarsomys sp. (Lavocat, 1973, 1978; Chaline et al., 1977), has been shown to be poorly founded (Carleton and Goodman, 1996). The extreme morphological diversity encompassed by the nine genera has confounded phylogenetic studies and discouraged identification of comparable cranial,

\section{TABLE 1}

Three Prominent Classifications of Nesomyine Genera

\begin{tabular}{|c|c|c|}
\hline Ellerman (1941) & Simpson (1945) & Lavocat (1978) \\
\hline $\begin{array}{l}\text { Family Muridae } \\
\text { Subfamily Murinae } \\
\text { Eliurus } \\
\text { murines } \\
\text { Subfamily Dendromyinae } \\
\text { Petromyscus } \\
\text { dendromurines } \\
\text { Subfamily Cricetinae } \\
\text { Nesomys } \\
\text { Hypogeomys } \\
\text { Calomyscus } \\
\text { Mystromys } \\
\text { Old World cricetines } \\
\text { New World cricetines } \\
\text { Subfamily Gymnuromyinae } \\
\text { Gymnuromys } \\
\text { Subfamily Tachyoryctinae } \\
\text { Brachyuromys } \\
\text { Tachyoryctes } \\
\text { Subfamily Microtinae } \\
\text { Brachytarsomys } \\
\text { arvicolines }\end{array}$ & $\begin{array}{l}\text { Superfamily Muroidea } \\
\text { Family Cricetidae } \\
\text { Subfamily Cricetinae } \\
\text { Subfamily Nesomyinae } \\
\text { Subfamily Lophiomyinae } \\
\text { Subfamily Microtinae } \\
\text { Subfamily Gerbillinae } \\
\text { Family Spalacidae } \\
\text { Family Rhizomyidae } \\
\text { Family Muridae } \\
\text { Subfamily Murinae } \\
\text { Subfamily Dendromurinae } \\
\text { Subfamily Otomyinae } \\
\text { Subfamily Phloeomyinae } \\
\text { Subfamily Rhynchomyinae } \\
\text { Subfamily Hydromyinae }\end{array}$ & $\begin{array}{l}\text { Superfamily Muroidea } \\
\text { Family Cricetodontidae } \\
\text { Subfamily Afrocricetodontinae } \\
\text { Family Nesomyidae } \\
\text { Subfamily Nesomyinae } \\
\text { Subfamily Lophiomyinae } \\
\text { Subfamily Mystromyinae } \\
\text { Subfamily Tachyoryctinae } \\
\text { Subfamily Gerbillinae } \\
\text { Subfamily Otomyinae } \\
\text { Family Muridae } \\
\text { Subfamily Murinae } \\
\text { Subfamily Dendromurinae }\end{array}$ \\
\hline
\end{tabular}


dental, or skeletal characters. A recent molecular phylogenetic study of Malagasy rodents used 12S rDNA to conclude that nesomyines are monophyletic with Cricetomys as their sister taxon (Dubois et al., 1996). However, this study suffers from incomplete taxon sampling as it included only three nesomyine genera (Eliurus, Nesomys and Macrotarsomys) and omitted most relevant African and Asian taxa (Mystromys, Petromyscus, Calomyscus, Tachyoryctes, and representatives of Dendromurinae).

Our primary goal in this paper is to investigate the monophyly of Nesomyinae. We include a thorough sampling of relevant murid taxa and use complete nucleotide sequence from the cytochrome $b$ gene as evidence of relationship. Taxon sampling encompasses all but two of the described species of nesomyines; the probable members of the archaic African murids (Mystromyinae, Petromyscinae, Dendromurinae, Cricetomyinae, and Tachyoryctes); both Asian and African representatives of Murinae; and Calomyscus, the only genus comprising the archaic Asian Calomyscinae. We use the resulting phylogeny to investigate the relationships among nesomyine genera and to examine their placement in murid evolutionary history. Finally, we present the first phylogenetic scenario for the origin of nesomyines and discuss its implications for murid biogeography.

\section{MATERIALS AND METHODS}

The entire cytochrome $b$ gene was sequenced for 103 specimens representing 32 species and putative species. This included 18 of the 21 recognized nesomyine species (84 individuals sequenced) and 14 representatives of Asian and African muroid taxa (19 individuals sequenced) (Table 2).

\section{Taxonomic Scope}

All but two of the specimens used in this study were wild caught animals; sequences from two species (Mus musculus and Rattus norvegicus) were taken from GenBank (Table 2, Appendix 1). Work on the alpha-taxonomy of nesomyines during the past decade (Carleton and Schmidt, 1990; Carleton, 1994; Carleton and Goodman, 1996; Goodman and Carleton, 1996; Carleton and
TABLE 2

Muroid Taxa Included in This Study, Their Country of Origin, and Number of Individuals Sequenced (in Parentheses)

$\begin{array}{ll}\text { Subfamily Nesomyinae } & \\ \text { Brachyuromys betsileoensis (4) } & \text { Madagascar } \\ \text { Brachyuromys ramirohitra (1) } & \text { Madagascar } \\ \text { Brachytarsomys albicauda (1) } & \text { Madagascar } \\ \text { Eliurus grandidieri (2) } & \text { Madagascar } \\ \text { Eliurus majori (11) } & \text { Madagascar } \\ \text { Eliurus minor (10) } & \text { Madagascar } \\ \text { Eliurus myoxinus (10) } & \text { Madagascar } \\ \text { Eliurus tanala (9) } & \text { Madagascar } \\ \text { Eliurus webbi }(8) & \text { Madagascar } \\ \text { Eliurus sp. A (1)* } & \text { Madagascar } \\ \text { Eliurus sp. B (3)* } & \text { Madagascar } \\ \text { Gymnuromys roberti (4) } & \text { Madagascar } \\ \text { Hypogeomys antimena (1) } & \text { Madagascar } \\ \text { Macrotarsomys bastardi (1) } & \text { Madagascar } \\ \text { Monticolomys koopmani (4) } & \text { Madagascar } \\ \text { Nesomys rufus (10) } & \text { Madagascar } \\ \text { Nesomys audeberti (2) } & \text { Madagascar } \\ \text { Voalavo gymnocaudus (2) } & \text { Madagascar }\end{array}$

Subfamily Cricetomyinae

Beamys hindei (2)

Cricetomys gambianus (1)

Cricetomys emini (4)

Tanzania and Kenya

Tanzania

Gabon, Kenya, and Ivory Coast

Subfamily Mystromyinae Mystromys albicaudatus (2)

South Africa

Subfamily Dendromurinae Steatomys parvus (2)

Kenya

Subfamily Rhizomyinae

Tachyoryctes splendens (1)

Kenya

Subfamily Murinae Apodemus sylvaticus (1)

Pakistan

Nesokia indica (1)

Pakistan

Mastomys hildebrandtii (1)

Hylomyscus alleni (1)

Mus musculus

Rattus norvegicus

Kenya

Gabon

Genbank accession V00711

Genbank accession J01436

Subfamily Petromyscinae

Petromyscus collinus (2)

Namibia

Subfamily Calomyscinae

Calomyscus baluchi (1)

Pakistan

* Species indeterminate pending further investigation.

Goodman, 1998; Goodman and Carleton, 1998) has increased the number of recognized species from 14 (Musser and Carleton, 1993) to 21 (Carleton and Goodman, 1998). In light of this ongoing revisionary work, 
several individuals of each nominate species from different collecting localities were included whenever available to better comprehend species limits and to investigate biogeographic questions within Madagascar. These questions will be discussed in future papers. The present phylogenetic study revealed two potentially new species of Eliurus. These are designated Eliurus sp. A and Eliurus sp. B pending further investigation.

\section{Molecular Methods}

Whole genomic DNA was extracted from frozen and buffer-preserved (10\% EDTA, 1\% NaF) tissues using QIAamp Whole Genomic Isolation kits (Qiagen Inc.). The entire cytochrome $b$ gene was PCR amplified using primers MVZ05 5'CGAAGCTTGATATGAAAAACCATCGTTG and UMMZ04 5'TCTTCATTTYWGGTTTACAAGAC. The entire gene was sequenced using these primers and primers UMMZ12 5'RTADGGGTGRAATGGRATTTTWTC and UMMZ13 5'CAYGAAWCAGGVTCAAAYAAYCC. PCR amplifications were done as standard $50-$ or $100-\mu \mathrm{L}$ reactions using AmpliTaq DNA Polymerase (Perkin-Elmer) on a Perkin-Elmer 480 Thermal Cycler using the following conditions: denaturation at $95^{\circ}$ for $1 \mathrm{~min}$; annealing at $50-55^{\circ}$ for $1 \mathrm{~min}$; extension at $72^{\circ}$ for $1 \min 15 \mathrm{~s}$; 30 cycles. All amplifications were preceded by a $95^{\circ}$ soak for $3 \mathrm{~min}$ and followed by a 7 -min extension at $72^{\circ}$. PCR products were prepared for automated sequencing by separation on a $2 \%$ agarose gel (NuSieve GTG, FMC Bioproducts) and subsequent purification using a QIAquick Gel Extraction kit (Qiagen Inc.). The gene was sequenced in two overlapping fragments in both directions using a Perkin Elmer Dye Termination Sequencing kit and an ABI 377 automated sequencer. All sequences were proofed and edited using Sequence Navigator ver. 1.0 (Applied Biosystems). Sequence data from this article have been deposited with GenBank under Accession Nos. AF160514-AF160614.

\section{Alignment and Parsimony Analysis}

DNA sequences were aligned using Clustal W (Thompson et al., 1994) and adjusted by eye. A single 3bp gap, corresponding to a codon deletion at basepairs 1135-1137, was introduced in Petromyscus and Tachyoryctes. This gap was treated as missing data in the final phylogenetic analysis; however, reanalysis with this gap coded as present or absent produced an identical topology. The resulting complete sequence matrix consisted of 104 taxa and 1143 characters. This matrix was condensed (filtered) using MacClade 3.05 (Maddison and Maddison, 1992), which removed uninformative sites and combined redundant taxa into a single terminal taxon. PAUP considered an additional six characters uninformative; thus, the final matrix consisted of 95 taxa and 540 informative characters.

Aligned sequences were subjected to parsimony analysis using PAUP 3.1 (Swofford, 1993) and PAUP* 4.064 (D. L. Swofford). All nucleotides were treated as unordered and unweighted in all analyses. Heuristic searches were conducted using the following two step search strategy: (1) an initial round of heuristic searching with 100 replicates of random stepwise addition of taxa, followed by tree-bisection-reconnection (TBR) branch-swapping with up to five trees saved from each replicate; (2) a second round of heuristic searching using the trees obtained in the initial search as starting trees, followed by TBR branch-swapping. The first step of this search strategy is designed to maximize the number of starting trees available for branch-swapping. In this case, a set of trees (maximum 500) was constructed with five trees from each of 100 random searches. This allows a more thorough and efficient exploration of available tree space than simply saving all trees resulting from branch-swapping on the results of a single search. The strict consensus of the resulting optimal trees was calculated and Calomyscus baluchi was designated as an outgroup (see discussion of rooting below).

Two measures of clade support were calculated. The Bremer Support Index is an unambiguous metric which gives the number of additional steps required to generate a nonminimal length tree in which a given clade does not appear (Bremer, 1988; Kallersjo et al., 1992). Bremer support values were calculated with the aid of TreeRot (Sorenson, 1996) and are expressed in the text as a fraction of the branch length, i.e., Bremer / branch length. Parsimony jackknife values were calculated for 10,000 replicates and a cut point of 50\% using JAC (Farris et al., 1996). Parsimony jackknifing randomly removes approximately one-third of the character data, calculates the most parsimonious tree based on this smaller data subset, and repeats this procedure $n$ (in this case 10,000) times. Each clade is given a 
parsimony jackknife value (PJV), which represents the percentage of replications in which that clade was recovered (Farris et al., 1996).

\section{RESULTS}

The initial heuristic search (100 replications of random stepwise addition, saving only 5 trees) resulted in a pool of 95 trees. The subsequent search using these 95 trees as starting trees resulted in 502 trees with length $=4373, \mathrm{CI}=0.22$, and $\mathrm{RI}=0.72$. In a strict consensus of these 502 trees, individuals from each of the nominate species cluster as a monophyletic assemblage (Fig. 1). Because this study is concerned with the more inclusive relationships among murid taxa, individuals were pruned from the complete cladogram to show only the basal structure among the taxa of interest. The resulting simplified cladogram shows phylogenetic structure with species, rather than individual organisms, as terminals (Fig. 2). Bremer support values and branch lengths are given for each node in Fig. 2, and the tree resulting from the parsimony jackknife search is shown in Fig. 3.

Cytochrome $b$ has been extensively used in phylogenetic work and has both supporters (Irwin et al., 1991) and detractors (Meyer, 1994; Graybeal, 1993). Those who have reservations about using the gene often advocate differential character weighting as a means of recovering reliable phylogenetic signal from a rapidly evolving gene (Griffiths, 1997; Swofford et al., 1996; Mindell and Thacker, 1996; Knight and Mindell, 1993). It is frequently argued that third position sites have been reduced to noise (i.e., saturated) and therefore provide unreliable (i.e., misleading) phylogenetic signal (Swofford et al., 1996) and should be downweighted or omitted. Others have argued that there is no rational basis for a priori differential character weighting or data set partitioning (Allard and Carpenter, 1996; DeSalle and Brower, 1997; Siddall, 1997) and that a priori weighting schemes are necessarily arbitrary. We evaluated the implications of treating the current data according to these alternative viewpoints by examining the retention index of the three codon positions on the total evidence tree. Of the 540 informative characters, 129 are first position changes, 48 are second position changes, and 363 are third position changes. As would be expected, second position changes are the most consistent on the total evidence tree ( $R I=0.82)$; however, first and third positions are not markedly less so ( $\mathrm{RI}=0.73$ and 0.71 , respectively). Because all three classes of data provide phylogenetic information across the entire tree, we do not differentially weight or exclude that information.

\section{DISCUSSION}

The resulting phylogenetic tree encompasses a wide range of hierarchical levels and allows consideration of several problems in nesomyine systematics. The data from cytochrome $b$ do not support nesomyine monophyly; however, they consistently reveal certain generic groupings among the nesomyines. Moreover, the resulting phylogeny sheds light on the biogeographic origin of the native Malagasy rodents. Each of these topics is discussed in turn below.

\section{Nesomyinae and Deeper Level Murid Systematics}

To assess the monophyly of the nesomyine rodents, it is necessary to determine their placement in Muridae. This is a daunting task as murid rodents are surely one of the most successful mammalian lineages, containing over 1300 extant species or nearly one-third of the 4600 recognized mammalian species. The scope can be narrowed considerably if we use prior classifications for delineating alternative phylogenetic hypotheses. The most explicit scenarios for the evolution of the nesomyine rodents are those of Lavocat $(1973,1978)$ and Chaline et al. (1977). According to these authors, the genera included in Nesomyinae, Dendromurinae, Petromyscinae, Cricetomyinae, and Mystromyinae are considered relicts of a cricetodontine stock present in Africa since the early Miocene. Carleton and Musser (1984) suggested that, with future research, the genera currently included in these subfamilies will be arrayed as tribes of an inclusive subfamily Nesomyinae and that the limits of these tribes will most likely not correspond to the current subfamilial definitions. We provide the first explicitly phylogenetic investigation of this contention. 


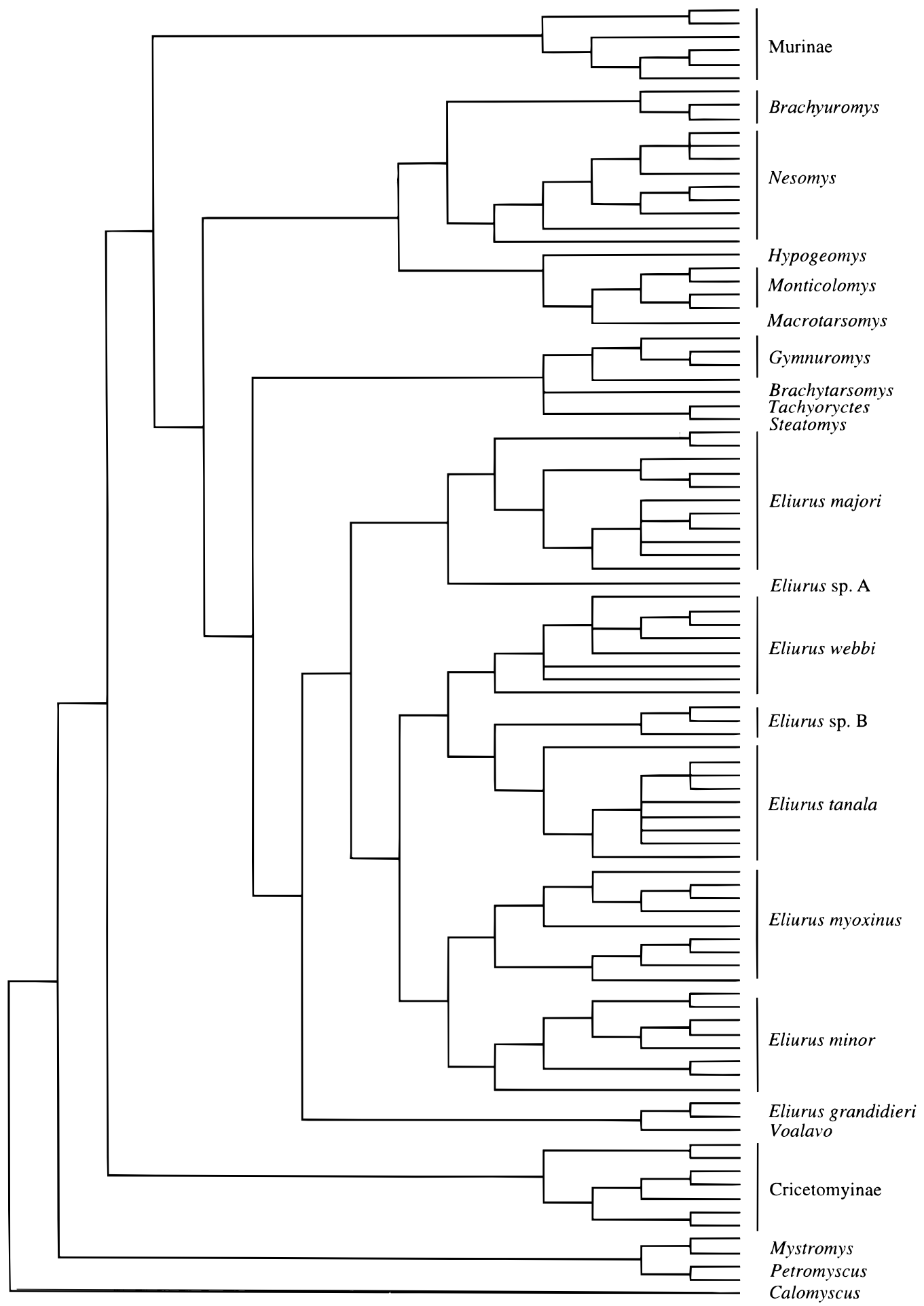

FIG. 1. Strict concensus of 502 most parsimonious cladograms obtained by heuristic search procedures of PAUP. Results are based on complete cytochrome $b$ sequence, which yielded 540 informative characters for 95 terminal taxa. Tree length $=4373, \mathrm{CI}=0.22, \mathrm{RI}=0.72$. 


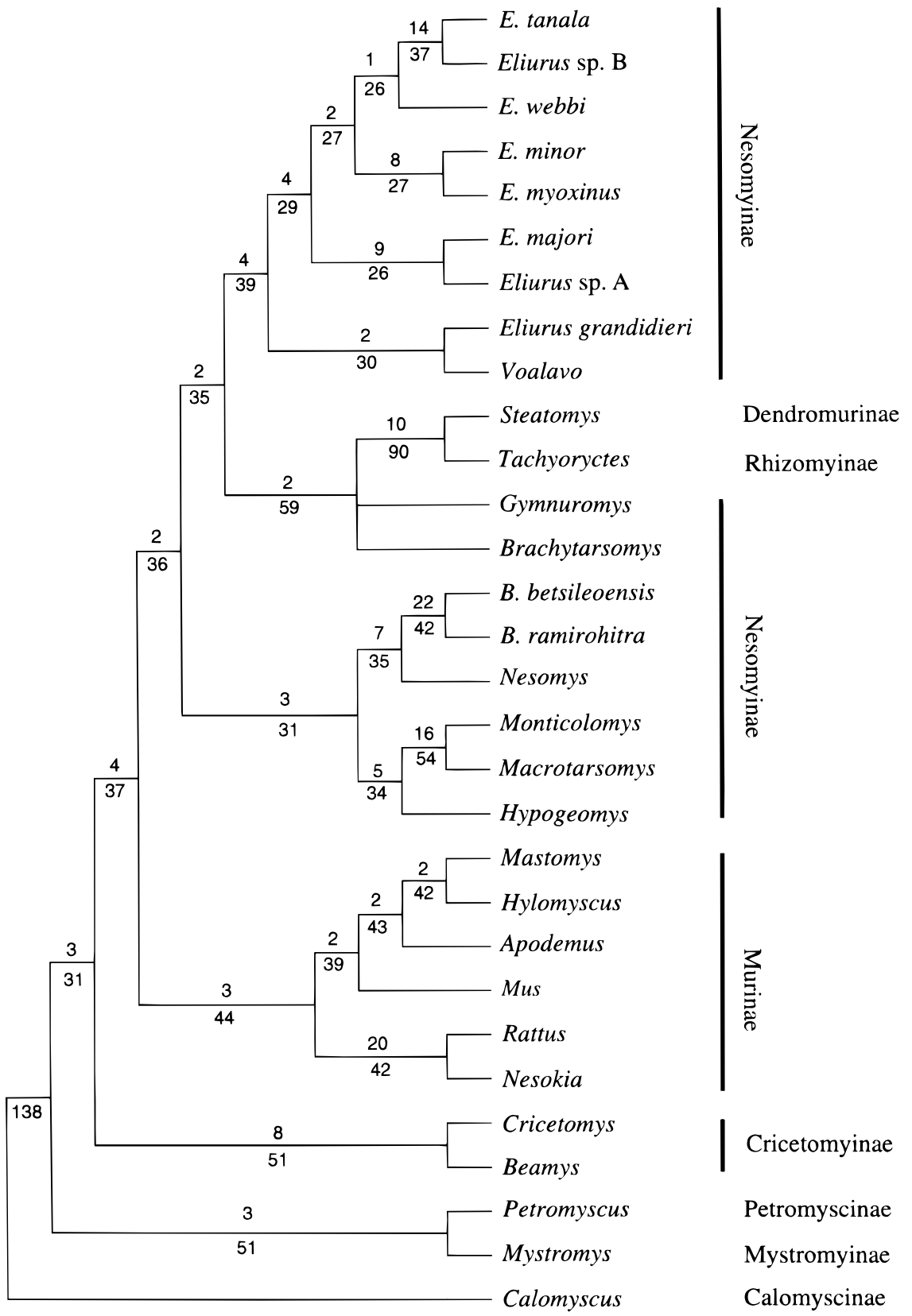

FIG. 2. Cladogram from Fig. 1 simplified to show basal structure among the taxa of interest. Individuals were pruned from the complete cladogram after parsimony analysis. Bremer Support values and branch length shown above and below the branch, respectively.

Interpretations of origin and directionality of murid phylogeny depend on where the network is rooted. We have chosen to root the tree using the Asian genus Calomyscus, the sole member of the muroid subfamily Calomyscinae. The phylogenetic position of Calomyscus within the muroid rodents is uncertain, but it is probably a primitive member of Muridae. Associations have been suggested with both New World (Pavlinov, 1980) and Old World cricetines (Vorontsov and Potapova, 1979), and more recently, Carleton and Musser (1984) suggested that Calomyscus is the sole remaining member of the otherwise extinct Asian 


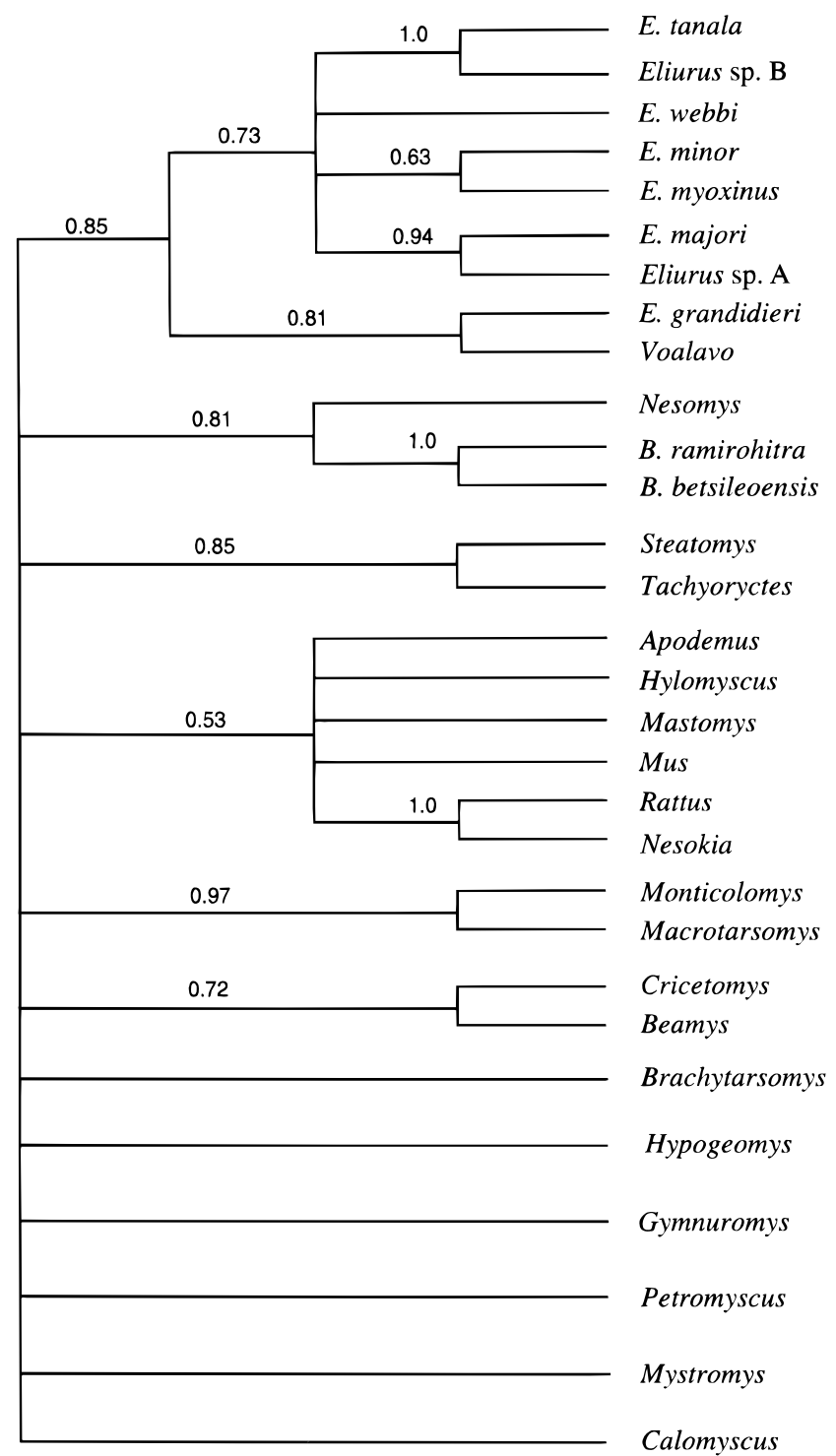

FIG. 3. Cladogram resulting from 10,000 random replications of parsimony jackknifing (JAC, Farris et al., 1996). Numbers indicate the percentage of replications in which the node was recovered; only values $>50 \%$ are shown.

group Cricetodontinae. Under any of these scenarios, Calomyscus provides an appropriate outgroup for the murid rodents included here and suggests that the murid tree is rooted in Asia. This geographic interpretation of murid origin is consistent with the fossil evidence; the earliest murid known to date is from the Eocene of China ( $\mathrm{Li}$ and Ting, 1983; VianeyLiaud, 1983).

\section{Nesomyinae, Dendromurinae, and Rhizomyinae}

The cytochrome $b$ data indicate that the subfamily Nesomyinae, as currently recognized, is not a monophyletic group. The nine nesomyine genera form a paraphyletic assemblage, with Dendromurinae (represented by Steatomys) and African Rhizomyinae (Tachyoryctes) included as part of the clade. The molecular data strongly support the sister group arrangement of Steatomys and Tachyoryctes (Bremer/branch length = $10 / 90$, PJV $=0.85$ ), suggesting that Tachyoryctes is part of the dendromurine assemblage rather than the sole African member of the otherwise Asian Rhizomyinae. However, this study cannot critically address this issue until the Asian rhizomyines Cannomys and Rhizomys and a broader sampling of dendromurine genera are included. Although the relationships suggested among nesomyines, the African rhizomyine, and dendromurines are intriguing, they are not well-supported by the cytochrome $b$ data (Figs. 2 and 3). Only 3 additional steps (out of 4373 total) are required to constrain nesomyines as a monophyletic group excluding Steatomys and Tachyoryctes.

\section{Mystromyinae and Petromyscinae}

The cytochrome $b$ phylogeny provides a critical test of the relationship between the enigmatic African genus Mystromys and the nesomyine genera. Ellerman (1941:445) professed to be "entirely at a loss to suggest the relationships of this genus, which seems not only isolated from the Palearctic and Neotropical genera, but to have no marked generic characters ...." Mystromys is considered by some authors to be the sole mainland African member of the subfamily Nesomyinae (Corbet and Hill, 1991). This view arose from the classification of muroid rodents produced by Chaline et al. (1977), who considered Mystromys and the nesomyines to be direct descendants of Afrocricetodontinae. However, a recent classification of Mammalia admits to the uncertain phyletic placement of Mystromys and places the genus as the sole member of the murid subfamily Mystromyinae (Musser and Carleton, 1993). The molecular data clearly refute any close relationship between Mystromys and the Malagasy genera, as the clade does not appear in the analysis, and an additional 25 steps (out of 4373) are required to force Mystromys to be the sister group of the nesomyines. 
In contrast, the molecular data suggest a sister group relationship between Mystromys and Petromyscus, one of two genera included in Petromyscinae. Petromyscus is another enigmatic muroid that has been variably included within Dendromurinae (Simpson, 1945; Ellerman, 1941), within Cricetidae (Petter, 1967, 1972), or within Petromyscinae in Muridae (Musser and Carleton, 1993). Several authors have remarked on the dental similarities between Mystromys and Petromyscus (Ellerman, 1941; Roberts, 1951; Lavocat, 1956), and Lavocat (1964) considered the petromyscine genera to be intermediate between Mystromys and the dendromurines. The molecular data tentatively support a sister group relationship between Mystromys and Petromyscus (Bremer/branch length $=3 / 51$, PJV $<50 \%$ ); the possible relationship between these two genera should receive further study, particularly relative to additional dendromurine genera and the second petromyscine genus, Delanymys.

\section{Cricetomyinae}

Cricetomyinae consists of three genera, Cricetomys, Beamys, and Saccostomus, which are diagnosed on the basis of a modified triserial molar pattern and shared internal cheek pouches (Ryan, 1989). The molecular data group Beamys and Cricetomys as sister taxa (Bremer/branch length $=8 / 51$; PJV $=0.72$ ), thus corroborating their association; however, to rigorously assess the monophyly of Cricetomyinae, the third genus in the subfamily should be included. The cricetomyine genera have been shuffled back and forth between Cricetidae and Muridae (sensu Simpson, 1945); this uncertainty results from two different interpretations of their molar morphology. The modified triserial pattern seen in the cricetomyine genera has been interpreted either as a simplified murid triserial pattern, in which case the medial cusps on the cricetomyine molars are homologous to similar cusps on the murine molar, or as an independent evolution of the triserial pattern, in which case these cusps are not homologous. In the molecular phylogeny, the cricetomyine rodents are placed as a basal member of the muroid rodents, a position which does not settle the controversy regarding their molar evolution. According to this tree, medial cusps may have evolved once in the ancestor to (Cricetomyinae + Murinae + Rhizomyinae + Dendromurinae) and were subsequently lost or modified in the ancestor to the (Nesomyinae + Dendromurinae + Rhizomyinae); alternatively, these cusps may have evolved independently in both Murinae and Cricetomyinae. Additional taxa and a combined analysis of morphological and molecular characters will provide a more appropriate test of this hypothesis than simply mapping the morphological characters on the present molecular tree (Kluge and Wolf, 1993; Jones et al., 1993; Eernisse and Kluge, 1993).

\section{Murinae}

This study was not designed to assess the monophyly of Murinae, a geographically widespread subfamily containing well over 500 species. The murines sampled include the African murine genera Hylomyscus and Mastomys, the widespread Eastern Hemisphere genera Mus and Apodemus (probably Asian in origin, Wessels et al., 1982), and the predominantly Asian Nesokia and Rattus. The present phylogeny clusters all six murine genera as a single monophyletic group and suggests that the African genera are derived relative to the murines of Asian origin. Paleontologists generally believe that murine rodents originated in Asia and spread from there throughout the Eastern Hemisphere; the earliest known murines are from the middle Miocene of Pakistan (Jacobs, 1978; Wessels et al., 1982), and murine fossils do not appear in Europe and Africa until the late Miocene (Jaeger, 1977; Lavocat, 1978). The phylogeny based on cytochrome $b$ is consistent with this view of murine biogeography in showing the African taxa Hylomyscus and Mastomys as derived relative to Rattus, Nesokia, Mus, and Apodemus, the murine taxa with presumed Asian origins (Jacobs, 1978; Wessels et al., 1982).

\section{Relationships among Nesomyine Genera}

The cytochrome $b$ phylogeny suggests that nesomyines form a paraphyletic group, but the basal relationships among nesomyines and other murid taxa are not well supported (Figs. 2 and 3) and deserve to be tested with additional taxa and characters. In contrast, several generic level affinities appear consistently in the cytochrome $b$ phylogeny and are well supported. These groupings are discussed below. 


\section{Eliurus and Voalavo}

A new nesomyine was recently discovered from the northern montane regions of Madagascar; this animal was described as the sole species of the new genus Voalavo (Carleton and Goodman, 1998). In their description of the genus, these authors report that Voalavo gymnocaudus is the sister taxon to the genus Eliurus (Carleton and Goodman, 1998). The molecular data support their contention that Voalavo is closely related to Eliurus, because the two genera form a clade to the exclusion of all other nesomyine genera. However, the molecular data suggest that Voalavo cannot be considered a separate genus without rendering Eliurus paraphyletic. According to the cytochrome $b$ cladogram, Voalavo is the sister taxon to Eliurus grandidieri (also described in Carleton and Goodman, 1998). Eliurus grandidieri and Voalavo gymnocaudus are only known from the northern highlands of Madagascar. The former species occurs in moist montane forest between 1210 and $1550 \mathrm{~m}$ and the latter species in montane and sclerophyllous forest from ca. 1300 to 1950 m (Goodman and Carleton, 1998). Monophyly of Eliurus and the new genus to the exclusion of all other genera is recovered in $85 \%$ of jackknife replications and that of Eliurus species excluding Eliurus grandidieri and Voalavo gymnocaudus is recovered in $73 \%$ of the replications. The clade conjoining Eliurus grandidieri and Voalavo is recovered in $81 \%$ of the 10,000 replications.

Meaningful confidence limits cannot be placed on any statistical measure of clade support, including parsimony jackknife values, and the use of resampling techniques as a measure of clade support remains controversial (Carpenter, 1992; Siddall, 1995; but see Hillis and Bull, 1993). The Bremer support value gives the number of extra steps required to lose a clade and, as such, is an unambiguous measure of the amount of corroboration the data give to a particular clade (Kallersjo et al., 1992; Bremer, 1994). The Bremer support values calculated for these taxa reveal a somewhat different picture of support than the parsimony jackknife values. The larger clade containing Eliurus and Voalavo receives a Bremer/branch length value of $4 / 39$ (PJV $=0.85)$, and it requires a similar 4 steps of 29 to dissolve the clade containing Eliurus species to the exclusion of E. grandidieri and Voalavo (PJV = 0.73).
However, the clade containing Voalavo and E. grandidieri has a relatively low Bremer/branch length value of $2 / 30$ despite its relatively high recovery rate of $81 \%$ in the parsimony jackknife analysis. Furthermore, it requires only three additional steps (out of 4373 total) to constrain the monophyly of Eliurus excluding Voalavo. These results serve to underscore the need for additional data to address the phylogenetic relationships among Eliurus species and Voalavo. Further studies would benefit from a combined analysis of the morphological and molecular data and the inclusion of the rare E. petteri (tissue samples not available for the present study), which Carleton and Goodman (1998) suggest is closely related to Eliurus grandidieri.

\section{Monticolomys, Macrotarsomys, and Hypogeomys}

Monticolomys koopmani is the sole species in a newly described genus from the forested high mountain regions of central and southern Madagascar. It ranks after Voalavo as the second smallest nesomyine species. The first specimen was collected in 1929, but was not recognized as unusual until the early 1970s by the late Karl Koopman (Carleton and Goodman, 1996). The enigmatic mouse was recently "rediscovered" in the wild in Madagascar by Goodman in 1993 and was formally described as a new genus and species by Carleton and Goodman in 1996. These authors were especially struck by the morphological similarity between Monticolomys and Macrotarsomys and tentatively suggested (1996:250) a phylogenetic link between the two:

several cranial and dental characters clearly implicate a sistergroup relationship between [Monticolomys] and Macrotarsomys ... to be sure, many more resemblences of Monticolomys and Macrotarsomys involve traits that are plausibly considered as primitive or those whose evolutionary polarity is equivocal ... at the same time ... we believe that a hypothesis of cognate affinity warrants attention at this formative stage of phylogenetic understanding among nesomyines.

The Monticolomys-Macrotarsomys clade is one of the most stable groupings present in the molecular phylogeny and is the most stable clade conjoining two nesomyine genera (Bremer/branch length $=16 / 54$; $\mathrm{PJV}=0.97$ ) (Figs. 2 and 3 ). The molecular data therefore 
strongly corroborate the sister group alliance of Monticolomys and Macrotarsomys suggested on the basis of morphological comparisons.

The sister group relationship between these two genera is intriguing as they are very different in their geographic distribution, habitat preferences, and ecological specializations. Macrotarsomys is restricted to the dry, deciduous forests and spiny forests of western and southern Madagascar. It has been referred to as the "Madagascar gerbil" based on its superficial resemblance to these desert-adapted rodents of Africa and Asia. In contrast, Monticolomys is generally murine in overall appearance and is restricted to eastern humid and montane sclerophyllous forest. Despite these ecological differences, both morphological and molecular data suggest the two share an immediate common ancestor.

Hypogeomys is the Malagasy giant jumping rat and is restricted to a small area of western, dry deciduous forests. Like Macrotarsomys, it has acquired bipedal, saltatorial locomotion; however, the burrow-dwelling Hypogeomys is by far the largest extant Malagasy rodent [although a larger subfossil species $H$. australis is known from Holocene deposits on the Central High Plateau and southeastern Madagascar (Goodman and Rakotondravony, 1996)]. In his taxonomic revision of Rodentia, Ellerman (1941) suggested affinities between Macrotarsomys and Hypogeomys based on external morphology and molar similarities. Ellerman relied on Milne-Edwards and Grandidier's (1898) comparison of Macrotarsomys and Hypogeomys as there were no specimens of Macrotarsomys in the British Museum at the time. Milne-Edwards and Grandidier's original drawing of Macrotarsomys molars are of an older individual with highly worn molars. As Schaub (1925) noted, molars from younger individuals do not resemble Hypogeomys, and molar structure provides no obvious basis for suggesting a sister group relationship between the two. Nonetheless, the tree derived from cytochrome $b$ data suggests that Hypogeomys is the sister taxon to the Monticolomys-Macrotarsomys clade. While this clade receives moderate Bremer Support (Bremer/branch length $=5 / 34$ ), it is not recovered in the parsimony jackknife analysis. Again, combined analysis of molecular and morphological data, and inclusion of the larger species of Macrotarsomys, M. ingens, will ultimately provide the strongest test of these phylogenetic hypotheses.

\section{Brachyuromys and Nesomys}

The African root-rat Tachyoryctes is a fossorial rodent adapted for subterranean habits in having a stocky, short-tailed body and robust skull that are well-suited for burrow excavation. Major $(1896,1897)$ was the first to propose that the Malagasy vole-like rodent Brachyuromys is simply a less-specialized form of Tachyoryctes. He based this conclusion on cranial and dental similarities, discounting the possibility that the morphological similarities between these two rodents could be the result of convergence rather than common ancestry. Major (1897:698) argued that by imagining a lessspecialized form of Tachyoryctes, one could conjure up Brachyuromys "if we divest the Tachyoryctes skull of its [excessive] fossorial characters and of the consequences of the more hypselodont molars, we obtain a Brachyuromys skull ... there is further a great correspondence in external characters if we disregard the smaller ears and eyes of Tachyoryctes." Ellerman (1940) concurred with Major (1897) and formalized his concept by erecting Tachyoryctinae for only these two genera. The molecular data support a sister group relationship between Brachyuromys and Nesomys (Bremer/ branch length $=7 / 35, \mathrm{PJV}=0.81$ ) (Figs. 2 and 3). Moreover, an additional 58 steps (of a total 4373) are required to constrain a Tachyoryctes-Brachyuromys clade, thus clearly refuting this relationship.

The sister group relationship apparent between Nesomys and Brachyuromys has not been suggested previously. Ellerman (1941) suggested that Brachyuromys has affinities with Hypogeomys but proposed a more immediate connection between Hypogeomys and Macrotarsomys (but see above discussion of Ellerman's possible confusion regarding Macrotarsomys). Petter (1961) suggested affinities between Nesomys and Hypogeomys based on similarities in general molar structure. The molecular data provide some resolution of these conflicting classificatory ideas. The present phylogenetic analysis uncovers a single clade containing these four genera (Hypogeomys, Macrotarsomys, Nesomys, and Brachyuromys) plus Monticolomys (described in 1996) 
and provides resolution as to the sister group relationships among them (Fig. 2).

\section{Brachytarsomys and Gymnuromys}

Brachytarsomys and Gymnuromys are two of the more enigmatic nesomyine genera. Gymnuromys has a laminate molar morphology unique among murid rodents, an observation which prompted Ellerman (1940) to erect a separate subfamily for this genus. The molars of Brachytarsomys are similar superficially to the prismatic molars present in the murid subfamily Arvicolinae (voles and lemmings). Major (1897) and Hinton (1926) proposed that Brachytarsomys is the "forerunner" to all voles and lemmings, but both authors stopped short of including Brachytarsomys and arvicoline murids in a single subfamily. Ellerman (1941), however, formally included Brachytarsomys in Arvicolinae (his Microtinae). Despite these taxonomic conclusions, it seems biogeographically unlikely that Brachytarsomys would share an immediate ancestor with the predominantly Holarctic Arvicolinae; therefore, this hypothesis was not addressed in the current study.

The molecular tree is moot with respect to the placement of Gymnuromys and Brachytarsomys, other than to suggest a relatively poorly supported association with the African rhizomyine Tachyoryctes and the dendromurine Steatomys (Bremer/branch length $=2 / 59$ ). Further taxonomic sampling, including the Asian rhizomyines and additional members of Dendromurinae, another questionably monophyletic murid subfamily (Verheyen et al., 1996) may aid in resolving the placement of these two genera.

\section{Biogeographic Implications}

Madagascar was originally part of the large Gondwanan supercontinent where it was situated between Africa and the Indian subcontinent (Du Toit, 1937; Smith and Hallam, 1970; Dietz and Holden, 1970; Krause et al., 1997). The continental connection between Africa and Madagascar was probably severed in the Middle to Late Jurassic (150-165 MYA) when Madagascar and India drifted south along the coast of Africa (Embleton and McElhinny, 1975; McElhinny and Embleton, 1976; McElhinny et al., 1976; Coffin and Rabinowitz, 1987). Ocean floor spreading data suggest that Madagascar reached its current position relative to Africa in the Early to Middle Cretaceous (124.5-133 MYA) (Martin and Hartanady, 1986; Segoufin and Patriat, 1981; Rabinowitz et al., 1983). The geology and biogeography of India are complicated, but geologists generally believe that India began its northward migration in the midCretaceous (88-90 MYA) (Storey et al., 1995; Storetvedt et al., 1992) and probably contacted Asia during the early Eocene (50-56 MYA) (Patriat and Achache, 1984; Besse and Courtillot, 1988; Klootwijk et al., 1992; Thewissen, 1990; Thewissen and McKenna, 1992; but see Patterson and Owen, 1991, and Jaeger et al., 1989, for evidence that contact occurred at the $\mathrm{K} / \mathrm{T}$ boundary). Thus, Madagascar has probably been isolated from other major Gondwanan landmasses at least since the Late Cretaceous, and these continents have been in their present position since the early Eocene.

Two main scenarios have been suggested for the origin of the rodent fauna on Madagascar: (1) nesomyine rodents are the result of a single invasion into Madagascar and a subsequent insular radiation; and (2) the endemic species resulted from several independent invasions of the island. The critical test of these propositions lies in identifying the appropriate muroid taxa to include in testing the monophyly of the nesomyines. Simpson (1952) and others have assumed that the ancestor(s) of the nesomyines arrived via waif dispersal from the African mainland. In this case, the likely relatives of the nesomyines should be found among the "archaic" African muroid taxa included in Dendromurinae, Cricetomyinae, Petromyscinae, and African Rhizomyinae. Less commonly considered is a possible Asian origin of the nesomyines. If the nesomyines arrived from Asia, their possible relatives may be found among Calomyscinae, Asian Rhizomyinae, or Murinae. We assessed these competing biogeographic alternatives by including examples of most of these subfamilies.

Superimposing the cladogram (Fig. 2) on a map of the Indo-African region (Fig. 4) supports the following three conclusions. First, given the root of the murid tree in Asia (discussed above), there are two independent invasions of Africa from Asia at the base of the tree, one which gave rise to Mystromys and Petromyscus, and a second which gave rise to the cricetomyines Beamys and Cricetomys. However, optimization of the ancestral area for these nodes is ambiguous. Alternately, one could propose an Asian origin for the murids, a single 


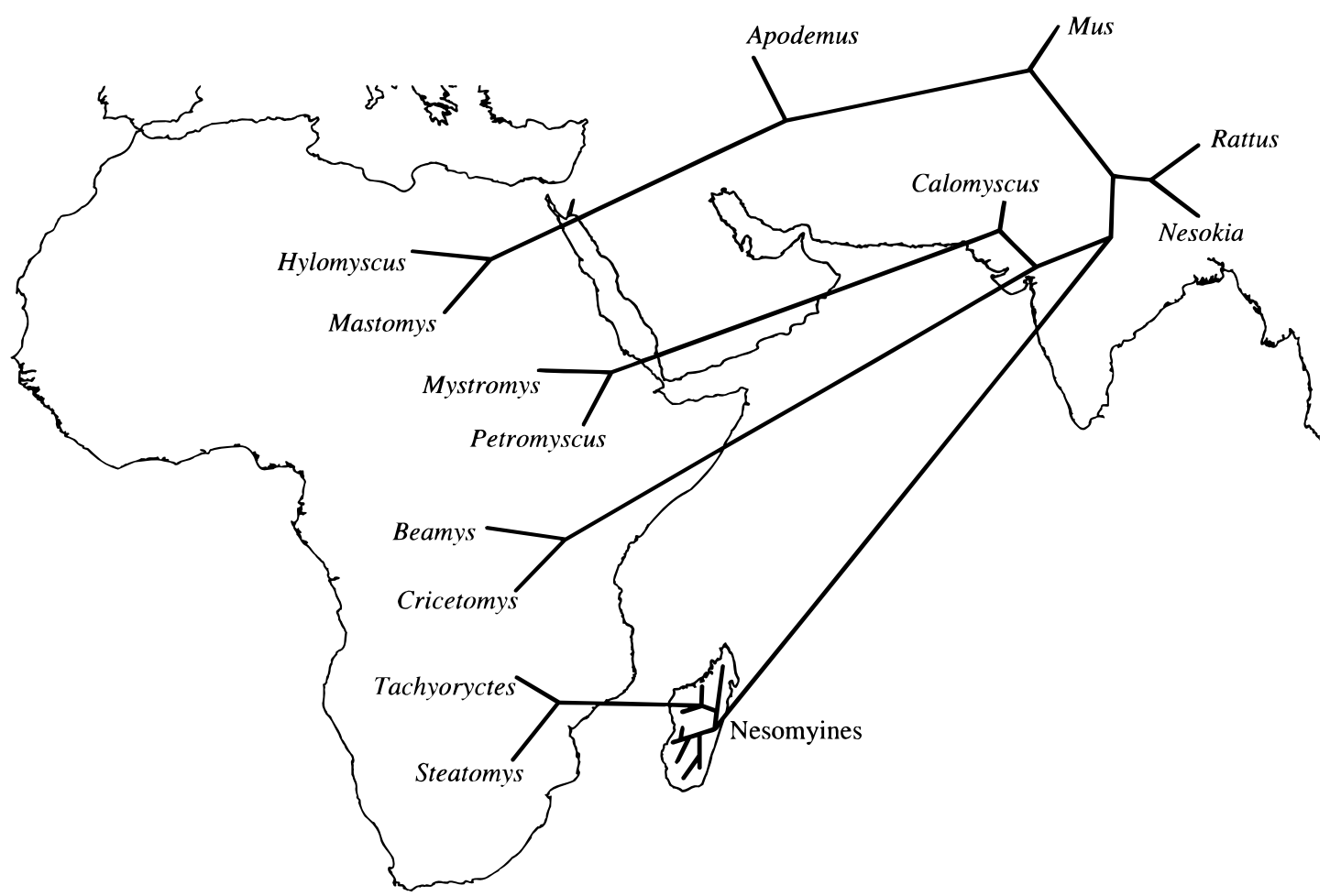

FIG . 4. Biogeographic scenario for the origin of the nesomyines and archaic African muroids. The cladogram from Fig. 2 was superimposed on a map of the Indo-Austrailian region. Assumptions used to generate this scenario and its possible implications for murid biogeography are discussed in the text.

African invasion giving rise to the two basal African clades, and a subsequent reinvasion of Asia to found the ancestor of the murines. Given that the earliest possible ancestor of all murids and of the more derived clade of murines are both found in the Asian fossil record, we consider the first optimization more defensible. Regardless of optimization, however, the molecular phylogenetic hypothesis suggests that the origin of the "archaic" African murids is complex.

Second, rodents arrived on Madagascar only once. The cytochrome $b$ phylogeny therefore supports the single origin hypothesis and suggests that the diversity of the nesomyine genera may have resulted from an insular adaptive radiation. Moreover, assuming that the ancestor of both murines and nesomyines arose in Asia, then the Malagasy rodents came from Asia, not from Africa as is commonly assumed (Fig. 4). This conclusion stands in contrast to the suggested origin of Madagascar's other native mammalian taxa. Yoder (1996) found that the Malagasy lemuriform primates form a monophyletic group which dispersed from Africa, the native Malagasy carnivores appear to have African affinities (M. Nedbal, pers. comm.), and insectivores have affinities to African (L. Olson, pers. comm.) or perhaps to New World taxa (Asher, 1997).

Finally, optimization of the ancestral areas unambiguously shows an invasion of the African mainland from Madagascar. This invasion gave rise to a single clade including Tachyoryctes (Rhizomyinae) and Steatomys (Dendromurinae). This intriguing result suggests that Tachyoryctes may not be closely related to the Asian rhizomyines, but rather to the Malagasy rodents and the African dendromurines. Further tests of this hypothesis require the inclusion of the Asian rhizomyines and additional dendromurine genera. Previous hypotheses of murid biogeography have not considered the possibility of dispersal from Madagascar to Africa; however, complex geographic histories have been suggested for other Malagasy organisms. Biogeographic analysis of gekkonid lizards show several dis- 
persal events between Madagascar and Africa (Kluge and Nussbaum, 1995), and a similarly complex history may be evident for chamaeleonines (Raxworthy and Nussbaum, pers. comm.).

\section{CONCLUSIONS AND CAVEATS}

The present molecular phylogenetic hypothesis of nesomyines contains the most thorough taxonomic sampling to date. The inclusion of all nesomyine genera, representatives from a majority of "archaic" African muroids (Mystromys, Petromyscus, Steatomys, Tachyoryctes, and two genera of Cricetomyinae) as well as several Asian taxa including Calomyscus, provides a severe test of nesomyine monophyly. The resulting phylogeny, based on complete cytochrome $b$ sequence data, indicates that the Malagasy rodents form a paraphyletic assemblage that includes the African genera Tachyoryctes (Rhizomyinae) and Steatomys (Dendromurinae). Despite this paraphyly, a single dispersal event to Madagascar can still explain the origin of the nesomyines and suggests that their morphological diversity may be the result of an adaptive radiation.

At first glance, the problem of nesomyine origins seems well suited to molecular data-the nesomyine genera are so morphologically diverse that phylogenetic inference based on morphological characters appears difficult. However, no particular "kind" of data is necessarily superior or inferior for addressing the systematics of the nesomyines. While morphological data may prove difficult to code for comparisons among these taxa, clearly molecular data from the cytochrome $b$ gene do not strongly corroborate their basal relationships. The systematic and biogeographic conclusions resulting from the present study are intriguing and in some cases novel; however, caution must be exercised before drawing any conclusions because not all parts of the underlying cladogram are strongly supported. The phylogeny presented here, and its attending biogeographic implications, is a hypothesis which is available for further testing with additional taxa and characters.

\section{ACKNOWLEDGMENTS}

S.A.J. gratefully acknowledges Michael Carleton for illuminating discussions of muroid systematics, Michael Sorenson for expert technical assistance, and Philip Myers for unselfishly providing computing resources. S.M.G.'s field work in Madagascar was facilitated by the Direction des Eaux et Forets, 1'Association Nationale pour la Gestion des Aires Protegees, and World Wildlife Fund for Nature. Additional tissue samples were generously donated by the Field Museum, the Smithsonian Institution, the Museum at Texas Tech, the Royal Ontario Museum, and Peter Taylor at the Durban Museum. Phil Myers, Michael Carleton, Arnold Kluge, Jennifer Ast, Laura Howard, and Mark Siddall provided helpful comments on earlier drafts. Laboratory work was supported in part by NSF DEB-9209950 to P.K.T. and by Dissertation Improvment Grant DEB-9623426, and grants from the Museum of Zoology, Department of Biology, and the Rackham School of Graduate Studies, University of Michigan, and the American Society of Mammalogists to S.A.J.

\section{APPENDIX 1}

\section{List of Specimens Sequenced and Their Vouchers}

\begin{tabular}{|c|c|c|}
\hline DNA No. & Species & Voucher specimen $^{a}$ \\
\hline \multicolumn{3}{|l|}{ Nesomyinae } \\
\hline 502 & Brachytarsomys albicauda & USNM 449212 \\
\hline 504 & Brachyuromys betsileoensis & USNM 449216 \\
\hline 505 & Brachyuromys betsileoensis & USNM 449217 \\
\hline 591 & Brachyuromys betsileoensis & FMNH 156227 \\
\hline 592 & Brachyuromys betsileoensis & FMNH 156229 \\
\hline 445 & Brachyuromys ramirohitra & FMNH 151659 \\
\hline 650 & Eliurus ellermani ${ }^{b}$ & FMNH 159697 \\
\hline 651 & Eliurus grandidieri & FMNH 159703 \\
\hline 655 & Eliurus grandidieri & FMNH 159699 \\
\hline 443 & Eliurus majori & FMNH 151667 \\
\hline 444 & Eliurus majori & FMNH 151732 \\
\hline 556 & Eliurus majori & FMNH 154610 \\
\hline 561 & Eliurus majori & FMNH 154289 \\
\hline 587 & Eliurus majori & FMNH 156503 \\
\hline 614 & Eliurus majori & FMNH 156616 \\
\hline 617 & Eliurus majori & FMNH 156345 \\
\hline 638 & Eliurus majori & FMNH 151661 \\
\hline 639 & Eliurus majori & FMNH 151662 \\
\hline 641 & Eliurus majori & FMNH 151664 \\
\hline 642 & Eliurus majori & FMNH 151731 \\
\hline 447 & Eliurus minor & FMNH 151673 \\
\hline 448 & Eliurus minor & FMNH 151675 \\
\hline 458 & Eliurus minor & FMNH 151669 \\
\hline 464 & Eliurus minor & FMNH 151672 \\
\hline 473 & Eliurus minor & FMNH 151734 \\
\hline 513 & Eliurus minor & USNM 448978 \\
\hline 514 & Eliurus minor & USNM 449246 \\
\hline
\end{tabular}


List of Specimens Sequenced and Their Vouchers Continued

\begin{tabular}{|c|c|c|}
\hline DNA No. & Species & Voucher specimen $^{a}$ \\
\hline 584 & Eliurus minor & FMNH 156618 \\
\hline 613 & Eliurus minor & FMNH 156211 \\
\hline 644 & Eliurus minor & U. Antananarivo \\
\hline 384 & Eliurus myoxinus & FMNH 151952 \\
\hline 385 & Eliurus myoxinus & FMNH 151953 \\
\hline 453 & Eliurus myoxinus & FMNH 151954 \\
\hline 570 & Eliurus myoxinus & FMNH 154633 \\
\hline 571 & Eliurus myoxinus & FMNH 154632 \\
\hline 590 & Eliurus myoxinus & FMNH 156630 \\
\hline 646 & Eliurus myoxinus & U. Antananarivo \\
\hline 647 & Eliurus myoxinus & U. Antananarivo \\
\hline 648 & Eliurus myoxinus & U. Antananarivo \\
\hline 653 & Eliurus myoxinus & U. Antananarivo \\
\hline 449 & Eliurus tanala & FMNH 151689 \\
\hline 463 & Eliurus tanala & FMNH 151687 \\
\hline 500 & Eliurus tanala & FMNH 151744 \\
\hline 511 & Eliurus tanala & USNM 448986 \\
\hline 583 & Eliurus tanala & FMNH 156631 \\
\hline 585 & Eliurus tanala & FMNH 156632 \\
\hline 586 & Eliurus tanala & FMNH 156634 \\
\hline 640 & Eliurus tanala & FMNH 151690 \\
\hline 643 & Eliurus tanala & USNM 448985 \\
\hline 573 & Eliurus undescribed $^{c}$ & U. Antananarivo \\
\hline 450 & Eliurus webbi & FMNH 151742 \\
\hline 454 & Eliurus webbi & FMNH 151680 \\
\hline 456 & Eliurus webbi & FMNH 151739 \\
\hline 459 & Eliurus webbi & FMNH 151682 \\
\hline 515 & Eliurus webbi & USNM 449257 \\
\hline 516 & Eliurus webbi & USNM 449259 \\
\hline 582 & Eliurus webbi & FMNH 156642 \\
\hline 652 & Eliurus webbi & FMNH 159718 \\
\hline 558 & Eliurus webbi? ${ }^{d}$ & FMNH 154623 \\
\hline 559 & Eliurus webbi? $^{d}$ & FMNH 154625 \\
\hline 506 & Gymnuromys roberti & USNM 449270 \\
\hline 441 & Gymnuromys roberti & FMNH 151693 \\
\hline 442 & Gymnuromys roberti & FMNH 151694 \\
\hline 594 & Gymnuromys roberti & FMNH 156614 \\
\hline 555 & Hypogeomys antimena & FMNH 154636 \\
\hline 595 & Macrotarsomys bastardi & U Antananarivo \\
\hline 618 & Monticolomys koopmani & FMNH 156212 \\
\hline 581 & Monticolomys koopmani & FMNH 156663 \\
\hline 589 & Monticolomys koopmani & FMNH 156661 \\
\hline 649 & Monticolomys koopmani & FMNH 159494 \\
\hline 509 & Nesomys audeberti & USNM 448893 \\
\hline 510 & Nesomys audeberti & USNM 448948 \\
\hline 451 & Nesomys audeberti? ${ }^{d}$ & FMNH 151696 \\
\hline 475 & Nesomys rufus & FMNH 151698 \\
\hline 476 & Nesomys rufus & FMNH 151745 \\
\hline 477 & Nesomys rufus & FMNH 151699 \\
\hline 496 & Nesomys rufus & FMNH 151747 \\
\hline 498 & Nesomys rufus & FMNH 151749 \\
\hline 501 & Nesomys rufus & FMNH 151915 \\
\hline 507 & Nesomys rufus & USNM 448898 \\
\hline 508 & Nesomys rufus & USNM 448899 \\
\hline 593 & Nesomys rufus & FMNH 156645 \\
\hline 540 & Voalavo gymnocaudus & FMNH 154040 \\
\hline 560 & Voalavo gymnocaudus & FMNH 154041 \\
\hline
\end{tabular}

List of Specimens Sequenced and Their Vouchers Continued

\begin{tabular}{|c|c|c|}
\hline DNA No. & Species & Voucher specimen $^{a}$ \\
\hline \multicolumn{3}{|c|}{ Mystromyinae } \\
\hline 634 & Mystromys albicaudatus & DM 3452 \\
\hline 635 & Mystromys albicaudatus & DM 4344 \\
\hline \multicolumn{3}{|l|}{ Murinae } \\
\hline & Mus musculus & GenBank \\
\hline & Rattus norvegicus & GenBank \\
\hline 580 & Nesokia indica & FMNH 140571 \\
\hline 588 & Apodemus sylvaticus & FMNH 140541 \\
\hline 137 & Mastomys hildebrantii & \\
\hline 124 & Hylomyscus alleni & \\
\hline \multicolumn{3}{|c|}{ Petromyscinae } \\
\hline 534 & Petromyscus collinus & TTU 55216 \\
\hline 535 & Petromyscus collinus & TTU 55218 \\
\hline \multicolumn{3}{|c|}{ Dendromurinae } \\
\hline 532 & Steatomys parous & CMNH 98494 \\
\hline 533 & Steatomys parvus & CMNH 98495 \\
\hline \multicolumn{3}{|l|}{ Rhizomyinae } \\
\hline 536 & Tachyoryctes splendens & CMNH 98212 \\
\hline \multicolumn{3}{|c|}{ Cricetomyinae } \\
\hline 517 & Beamys hindei & FMNH 151225 \\
\hline 529 & Beamys hindei & CMNH 98246 \\
\hline 530 & Cricetomys emini & CMNH 90808 \\
\hline 531 & Cricetomys emini & CMNH 98248 \\
\hline 636 & Cricetomys emini & ROM 100510 \\
\hline 637 & Cricetomys emini & ROM 100511 \\
\hline 518 & Cricetomys gambianus & FMNH 151227 \\
\hline \multicolumn{3}{|c|}{ Calomyscinae } \\
\hline 576 & Calomyscus baluchi & FMNH 140412 \\
\hline
\end{tabular}

${ }^{a}$ USNM, National Museum of Natural History; FMNH, Field Museum of Natural History; CMNH, Carnegie Museum of Natural History; TTU, The Museum, Texas Tech University; ROM, Royal Ontario Museum; and DM, Durban Museum, South Africa.

${ }^{b}$ Identified as Eliurus ellermani, referred to here as Eliurus sp. B pending further investigation. Eliurus webbi 558 and 559 referred to as Eliurus sp. B pending further investigation.

${ }^{c}$ Undescribed Eliurus referred to here as Eliurus sp. A.

${ }^{d}$ Questionable N. auderberti. See discussion of species identification in Carleton and Goodman (1996:273).

\section{REFERENCES}

Allard, M. W., and Carpenter, J. M. (1996). On weighting and congruence. Cladistics 12, 183-198.

Asher, R. J. (1997). African and Malagasy tenrecs: A biogeographic parallel with lemuriform primates? Am. J. Phys. Anthropol. 24, (Suppl.) 69-70.

Besse, J., and Courtillot, V. (1988). Paleogeographic maps of the continents bordering the Indian Ocean since the early Jurassic. J. Geophys. Res. 93, 11791-11808. 
Bremer, K. (1988). The limits of amino acid sequence data in phylogenetic reconstruction. Evolution 42, 795-803.

Bremer, K. (1994). Branch support and tree stability. Cladistics 10, 295-304.

Carleton, M. D. (1994). Systematic studies of Madagascar's endemic rodents (Muroidea: Nesomyinae): Revision of the genus Eliurus. Am. Mus. Novitates 3087, 55.

Carleton, M. D., and Goodman, S. M. (1996). Systematic studies of Madagascar's endemic rodents (Muroidea: Nesomyinae): A new genus and species from the Central Highlands. In "A Floral and Faunal Inventory of the Eastern Slopes of the Reserve Naturelle Intégrale d' Andringitra, Madagascar: With Reference to Elevational Variation." (S.M. Goodman, Ed.), Zoology, New Series No. 85, pp. 231-250, Fieldiana.

Carleton, M. D., and Goodman, S. M. (1998). New taxa of nesomyine rodents (Muroidea: Muridae) from Modagascar's northern highlands, with taxonomic comments on previously described forms. In "A Floral and Faunal Inventory of the Réserve Spéciale d'Anjanaharibe-Sud, Madagascar: With Reference to Elevational Variation." (S. M. Goodman, Ed.), Zoology, New Series No. 90, pp. 163-200, Fieldiana.

Carleton, M. D., and Musser, G. G. (1984). Muroid rodents. In "Orders and Families of Recent Mammals of the World." (S. Anderson, J. K. Jones, Jr., Eds.), Wiley Sons, New York. pp. 289-379.

Carleton, M. D., and Schmidt, D. F. (1990). Systematic studies of Madagascar's endemic rodents (Muroidea: Nesomyinae): An annotated gazetteer of collecting localities of known forms. Am. Mus. Novitates 2987, 36.

Carpenter, J. M. (1992). Random cladistics. Cladistics 8, 147-153.

Chaline, J. P., Mein, P., and Petter, F. (1977). Les grands lignes d'une classification evolutive des Muroidea. Mammalia 41, 245-252.

Coffin, M. F., and Rabinowitz, P. D. (1987). Reconstruction of Madagascar and Africa: Evidence from the Davie Fracture Zone and Western Somali Basin. J. Geophys. Res. 92(B9), 9385-9406.

Corbet, G. B., and Hill, J. E. (1991). "A World List of Mammalian Species.” Natural History Museum Publications, Oxford Univ. Press.

DeSalle, R., and Brower, A. V. Z. (1997). Process partitions, congruence, and the independence of characters: Inferring relationships among closely related Hawaiian Drosophila from multiple gene regions. Syst. Biol. 46, 751-764.

Dietz, R. S., and Holden, J. C. (1970). Reconstruction of Pangaea: Breakup and dispersion of continents, Permian to present. J. Geophys. Res. 75, 4939-4956.

Dubois, J.-Y., Rakotondravony, D., Hänni, C., Sourrouille, P., and Catzeflis, F. F. (1996). Molecular evolutionary relationships of three genera of Nesomyinae, endemic rodent taxa from Madagascar. $J$. Mamm. Evol. 3, 239-260.

Du Toit, A. L. (1937). "Our Wandering Continents: An Hypothesis of Continental Drifting." Oliver and Boyd, Edinburgh.

Eernisse, D. J., and Kluge, A. G. (1993). Taxonomic congruence versus total evidence, and amniote phylogeny inferred from fossils, molecules, and morphology. Mol. Biol. Evol. 10, 1170-1195.

Ellerman, J. R. (1940). "The Families and Genera of Living Rodents.
Vol I. Rodents Other Than Muridae." British Museum (Natural History), London.

Ellerman, J. R. (1941). "The Families and Genera of Living Rodents. Vol II. Family Muridae.” British Museum (Natural History), London.

Embleton, B. J. J., and McElhinny, M. W. (1975). The palaeoposition of Madagascar: Palaeomagnetic evidence from the Isalo group. Earth Planet. Sci. Lett. 27, 329-341.

Farris, J. S., Albert, V. A., Källersjö, M., Lipscomb, D., and Kluge, A. G. (1996). Parsimony jackknifing outperforms neighbor-joining. Cladistics 12(2), 99-124.

Goodman, S. M., and Carleton, M. D. (1996). The rodents of the Réserve Naturelle Intégrale d' Andringitra, Madagascar. In "A Floral and Faunal Inventory of the Eastern Slopes of the Réserve Naturelle Intégrale d'Andringitra, Madagascar: With Reference to Elevational Variation. (S. M. Goodman, Ed.), Zoology, New Series No. 85, pp.231-250, Fieldiana.

Goodman, S. M., and Carleton, M. D. (1998). The rodents of the Réserve Spéciale d'Anjanaharibe-Sud. In "A Floral and Faunal Inventory of the Réserve Spéciale d'Anjanaharibe-Sud, Madagascar: With Reference to (S. M. Goodman, Ed.), Elevational Variation." Zoology, New Series No. 90, pp. 201-221, Fieldiana.

Goodman, S. M., and Rakotondravony, D. (1996). The Holocene distribution of Hypogeomys (Rodentia: Muridae: Nesomyinae) on Madagscar. In "Biogéographie de Madagascar" (W. R. Lourenço, Ed.), L'ORSTOM, Paris.

Graybeal, A. (1993). The phylogenetic utility of cytochrome $b$ : lessons from bufonid frogs. Mol. Phyl. Evol. 2(3), 256-269.

Griffiths, C. S. (1997). Correlation of functional domains and rates of nucleotide substitution in cytochrome b. Mol. Phyl. Evol. 7, 352-365.

Hillis, D. M., and Bull, J. J. (1993). An empirical-test of bootstrapping as a method for assessing confidence in phylogenetic analysis. Syst. Biol. 42, 182-192.

Hinton, M. A. C. (1926). "Monograph of the Voles and Lemmings (Microtinae) Living and Extinct," Vol. 1. British Museum (Natural History), London.

Irwin, D. M., Kocher, T. D., and Wilson, A. C. (1991). Evolution of the cytochrome-b gene of mammals. J. Mol. Evol. 32, 128-144.

Jacobs, L. L. (1978). Fossil rodents (Rhizomyidae and Muridae) from Neogene Siwalik deposits, Pakistan. Mus. of N. Ariz. Bull. Ser. 52, $1-103$.

Jaeger, J.-J. (1977). Les rongeurs du Miocène Moyen et Supérieur du Maghreb. Palaeovertebrata 8, 1-166.

Jaeger, J.-J., Courtillot, V., and Taponnier, P. (1989). Paleontological view of the ages of the Deccan Traps, the Cretaceous/Tertiary boundary, and the India-Asia collision. Geology 17, 316-319.

Jones, T. R., Kluge, A. G., and Wolf, A. J. (1993). When theories and methodologies clash: A phylogenetic reanalysis of the North American ambystomatid salamanders (Caudata: Ambystomatidae). Syst. Biol. 42, 92-102.

Källersjö, M., Farris, J. S., Kluge, A. G., and Bult, C. (1992). Skewness and permutation. Cladistics 8, 275-287.

Klootwijk, C. T., Gee, J. S., Peirce, J. W., Smith, G. M., and McFadden, P. L. (1992). An early India-Asia contact: Paleomagnetic constraints from Ninetyeast Ridge, ODP Leg 121. Geology 20, 395-398. 
Kluge, A. G., and Wolf, A. J. (1993). Cladistics: What's in a word? Cladistics 9, 183-199.

Kluge, A. G., and Nussbaum, R. A. (1995). A review of AfricanMadagascan gekkonid lizard phylogeny and biogeography (Squamata). Misc. Pub. Mus. Zool. Univ. Michigan. No. 183.

Knight, A., and Mindell, D. P. (1993). Substitution bias, weighting of DNA-sequence evolution, and the phylogenetic position of Fea's viper. Syst. Biol. 42, 18-31.

Krause, D. W., Hartman, J. H., and Wells, N.A. (1997). Late Cretaceous vertebrates from Madagascar: implications for biotic change in deep time. In "Natural Change and Human Impact in Madagascar" (S. M. Goodman and B. D. Patterson, Eds.), pp. 3-43. Smithsonian Institution Press, Washington.

Lavocat, R. (1956). La faune de rongeurs des grottes a Autralopithèques. Palaeontologia Africana 4, 69-75.

Lavocat, R. (1964). On the systematic affinities of the genus Delanymys Hayman. Proceedings of the Linnean Society of London, 175, $183-185$.

Lavocat, R. (1973). Les rongeurs du Miocène d'Afrique Oriéntale. Mém. Trav. l'Ecole Prat. Hautes Etudes, Montpellier. 1, 1-284.

Lavocat, R. (1978). Rodentia and Lagomorpha. In "Evolution of African Mammals" (V. J. Maglio and H. B. S. Cooke, Eds.), pp. 69-89, Harvard Univ. Press, Cambridge.

Li, C.-K., and Ting, S.-Y. (1983). Possible phylogenetic relationship of Asiatic Eurymylids and rodents, with comments on Mimotonids. In "Evolutionary Relationships Among Rodents: A Multidisciplinary Analysis" (W. P. Luckett and J. L. Hartenberger, Eds.), Plenum Press, New York.

Maddison, W. P., and Maddison, D. R. (1992). "MacClade ver. 3.0: Analysis of Phylogeny and Character Evolution." Sinauer Associates, Sunderland, MA.

Major, C. I. F[orsyth]. (1896). On the general results of a zoological expedition to Madagascar in 1894-96. Proc. Zool. Soc. London 971981.

Major, C. I. F[orsyth]. (1897). On the Malagasy rodent genus Brachyuromys; and on the mutual relations of some groups of the Muridae (Hesperomyinae, Microtinae, Murinae, and "Spalacidae") with each other and with the Malagasy Nesomyinae. Proc. Zool. Soc. London 695-720.

Martin, A. K., and Hartanady, C. J. H. (1986). Plate tectonic development of the south west Indian Ocean: A revised reconstruction of east Antarctica and Africa. J. Geophys. Res. 91, 4767-4786.

McElhinny, M. W., and Embleton, B. J. J. (1976). The palaeoposition of Madagascar: Remanence and magnetic properties of late Palaeozoic Sediments. Earth Planet. Sci. Lett. 31, 101-112.

McElhinny, M. W., Embleton, B. J. J., Daly, L., and Pozzi, J.-P. (1976). Paleomagnetic evidence for the location of Madagascar in Gondwanaland. Geology 4, 455-457.

Meyer, A. (1994). Shortcomings of the cytochrome $b$ gene as a molecular marker. TREE 9, 278-280.

Milne-Edwards, A., and Grandidier, G. (1898). Description d'une espèce nouvelle de Muridé provenant de Madagascar. Bull. Mus. Hist. Nat., Paris. Série 1, 4,179-181.

Mindell, D. P., and Thacker, C. E. (1996). Rates of molecular evolution: phylogenetic issues and applications. Annu. Rev. Ecol. Syst. 27, 279-303.

Musser, G. G., and Carleton, M. D. (1993). Family Muridae. In "Mammal Species of the World" (D. E. Wilson and D. M. Reeder, Eds.), pp. 501-753. Smithsonian Institution Press, Washington.

Patriat, P., and Achache, J. (1984). India-Eurasia collision chronology has implications for crustal shortening and driving mechanism of plates. Nature 311, 615-621.

Patterson, C., and Owen, H. G. (1991). Indian isolation or contact? A response to Briggs. Syst. Zool. 40, 96-100.

Pavlinov, I. Ya. (1980). Taxonomic status of Calomyscus Thomas (Rodentia, Cricetidae) on the basis of structure of auditory ossicles. Zool. Zhur. 59, 312-316.

Petter, F. (1961). Monophylétisme ou polyphylétisme des rongeurs malgaches. Problèms Actuels de Paléontologie (Evolution des vertebrés). Colloques Internationaux du Centre de la Recherche Scientifique. 104, 301-310.

Petter, F. (1967). Particularities dentaires des Petromyscinae Roberts 1951 (Rongeurs, Cricetides). Mammalia 31, 217-224.

Petter, F. (1972). The rodents of Madagascar: the seven genera of Malagasy rodents. In "Biogeography and Ecology in Madagascar" (R. Battistini and G. Richard-Vindard, Eds.), pp. 661-665. W. Junk, B. V. Publishers, The Hague.

Rabinowitz, P. D., Coffin, M. F., and Falvey, D. (1983). The separation of Madagascar and Africa. Science 220, 67-69.

Roberts, A. (1951). "The Mammals of South Africa. Trustees of 'The Mammals of South Africa' Book Fund," Johannesburg.

Ryan, J. M. (1989). Evolution of cheek pouches in African pouched rats (Rodentia: Cricetomyinae). J. Mamm. 70, 267-274.

Schaub, S. (1925). Die hamsterartigen Nagetiere des Tertiärs und ihre lebenden Verwandten. Abh. Schweiz. Pal. Ges. 45

Ségoufin, J., and Patriat, P. (1981). Reconstructions de l'océan Indien occidental pour les époques des anomalies M21, M2 et 34. Paléoposition de Madagascar. Bull. Soc. Géolog. France. 23, 603-607.

Siddall, M. E. (1995). Another monophyly index: Revisiting the jackknife. Cladistics 11, 33-56.

Siddall, M. E. (1997). Prior agreement: Arbitration or arbitrary? Syst. Biol. 46, 765-769.

Simpson, G. G. (1945). The principles of classification and a classification of mammals. Bull. Am. Mus. Nat. Hist. 85, 1-350.

Simpson, G. G. (1952). Probabilities of dispersal in geologic time. Bull. Am. Mus. Nat. Hist. 99, 163-176.

Smith, A. G., and Hallam, A. (1970). The fit of the southern continents. Nature 225, 139-144.

Sorenson, M. D. (1996). "TreeRot." University of Michigan, Ann Arbor.

Storey, M., Mahoney, J. J., Saunders, A. D., Duncan, R. A., Kelley, S. P., and Coffin, M. F. (1995). Timing of hot spot-related volcanism and the breakup of Madagscar and India. Science 267, 852-855.

Storetvedt, K. M., Mitchell, J. G., Abranches, M. C., Maaloe, S., and Robin, G. (1992). The coast-parallel dolerite dykes of East Madagascar; age of intrusion, remagnetization and tectonic aspects. J. Af. Earth Sci. 15, 237-249. 
Swofford, D. L. (1993). "PAUP (Phylogenetic Analysis Using Parsimony)". Ver. 3.1. Center for Biodiversity, Illinois Natural History Survey.

Swofford, D. L., Olsen, G. J., Waddell, P. J., and Hillis, D. M. (1996). Phylogenetic Inference. In "Molecular Systematics" (D. M. Hillis, C. Moritz, and B. K. Mable, Eds.), pp. 407-514. second ed. Sinauer Associates, Sunderland, MA.

Thewissen, J. G. M. (1990). Comments and Reply on "Paleontological view of the ages of the Deccan Traps, the Cretaceous/Tertiary boundary, and the India-Asia collision." Geology 18, 185-188.

Thewissen, J. G. M., and McKenna, M. C. (1992). Paleobiogeography of Indo-Pakistan: A response to Briggs, Patterson, and Owen. Syst. Biol. 41, 248-251.

Thompson, J. D., Higgins, D. G., and Gibson, T. J. (1994). CLUSTAL$\mathrm{W}$-Improving the sensitivity of progressive multiple sequence alignment through sequence weighting, position-specific gap penalties and weight matrix choice. Nucleic Acids Res 22, 4673-4680.
Verheyen, E., Colyn, M., and Verheyen, W. (1996). A mitochondrial cytochrome $b$ phylogeny confirms the paraphyly of the Dendromurinae Alston, 1896 (Muridae, Rodentia). Mammalia 60, 780-785.

Vianey-Liaud, M. (1983). Possible evolutionary relationships among Eocene and lower Oligocene rodents of Asia, Europe and North America. In "Evolutionary Relationships Among Rodents: A Multidisciplinary Analysis" (W. P. Luckett and J. L. Hartenberger, Eds). Plenum Press, New York.

Vorontsov, N. N., and Potapova, E. G. (1979). Taxonomy of the genus Calomyscus (Cricetidae). 2. Status of Calomyscus in the system of Cricetinae. Zool. Zhur. 58, 1391-1397.

Wessels, W., de Bruijn, H., Hussain, S. T., and Leinders, J. J. M. (1982). Fossil rodents from the Chinji formation, Banda Daud Shah, Kohat, Pakistan. Kon. Ned. Akad. Wetensch. Proc., Ser. B 85, 337-364.

Yoder, A. D. (1996). The use of phylogeny for reconstructing Lemuriform biology. In: W. R. Lourenço (ed.) Biogéographie de Madagascar. L'ORSTOM, Paris. 